\title{
Sustainable Approaches Towards Aquaculture: Microalgal Circular Economy Perspectives
}

\section{Bharti Mishra}

Amity University

Archana Tiwari ( $\square$ panarchana@gmail.com )

Amity University https://orcid.org/0000-0001-7172-2623

Alaa El Din Mahmoud

Alexandria University Faculty of Science

\section{Research Article}

Keywords: Aquaculture, Aquafeed, Biocidal, Microalgae, Nutraceuticals

Posted Date: February 9th, 2021

DOI: https://doi.org/10.21203/rs.3.rs-166803/v1

License: (1) This work is licensed under a Creative Commons Attribution 4.0 International License. Read Full License 


\section{Abstract}

Microalgae have higher nutritional value as they are abundant in protein, carbohydrates, lipids, and vitamins. Hence, they play several important roles in aquaculture and are known as a major source of the food chain for aquaculture organisms. Furthermore, they are also used indirectly or directly by humans as

food supplements and medicines to improve health by strengthening the immune system. Microalgae are used as biocontrol agents because they have biocidal properties, produce biomolecules (beta carotene, PUFA, and astaxanthin), wastewater, are a renewable resource of biofuel, and are used in wastewater treatment. Due to the overexploitation of wild fish and pollution, aquaculture faces serious issues. Ecofriendly methods are required to overcome this problem, so, microalgae are in practicing, that control the water pollution. Fishmeal is a rich source of protein in aquaculture but it is decreasing over time and has become cost-effective, so, to solve the problem, microalgae are used to replace the fishmeal which (microalgae as aquafeed) is cheap and not required large area to grow. Microalgae are seemed to be very useful in the growth enhancement of aquatic organisms.

\section{Introduction}

Aquaculture is derived from 'aqua' means 'water' and 'culture' means 'cultivation'. It is the process to cultivate the aquaculture of organisms or animals. Aquaculture is one of the fastest-growing industries and even three times faster than the land animal industry, which feeds about $47 \%$ of human fish consumption so, its production growing continuously (Ansari et al., 2019). This growing industry improves the economic condition due to its high global demand and helps to reduce hunger, poverty, and many other things (Halima, 2018).

It is reported that 4.8 billion pounds earned annually by Americans from seafood and $90 \%$ of fish imported from China in the USA (Healey et al., 2016). Apart from that, as fish farming increasing, some serious problems related to that also increasing like an overpopulation of wild fish and pollution in aquaculture. To overcome this problem, the practice of eco-friendly fish farming is in use for example, microalgae are used as fish feed (Tossavainen et al., 2018).

Algae are photosynthetic organisms and living as unicellular or as multicellular organisms. They are present everywhere around the world (water), they provide food for many aquatic animals, and so, they are known as primary producers (Brown et al., 2013). The more important algae are belonging to green algae (Chlorophyceae), red algae (Rhodophyceae), diatoms (Bacillariophyceae), and brown algae (Phaeophyceae) groups. Algae are divided as macroalgae and microalgae. Macroalgae (seaweeds) are multicellular, and they are very long and extend for more than a few meters long (Markou et al., 2012) while microalgae are single-celled, microscopic plants present in freshwater and marine water (Brown et al., 2013). Most of the microalgal species are autotrophic but some of the species are heterotrophic such as Polytoma sp. and Polytomella sp. and having degenerated chloroplast (Talero et al., 2015). 
Microalgae known as the earliest life form on the earth, they acclimatize themselves as well as their metabolism in several environments. Microalgae have a high growth rate in appropriate conditions, and they can grow in wastewater or sewage water (Han et al., 2019). Microalgae are rich in nutrients (protein, carbohydrate, and lipids) and it is considered as the base of the food chain in aquaculture. They are used as food supplements by aquaculture organisms, direct or indirect way. All stages of bivalve mollusk and the larval or juvenile stages of fish eat the microalgae (Brown et al., 2013). Reported that microalgae are also a rich source of vitamins and minerals like vitamin A, B1, B2, C, and E; folic acid, magnesium, iron, iodine, and calcium, etc. (Sathasivam et al., 2017a) thus all these quality make them edible or beneficial and reduce the traditional feed materials that may not have sufficient nutrient and growth rate on aquatic organisms as microalgae have (Shah et al., 2018).

Microalgae use sunlight, nutrients, and carbon dioxide or carbonate for their growth and lipids synthesis (Sirakov et al., 2015). By fixing $\mathrm{CO}_{2}$, they can transform solar energy into chemical energy which is more efficient than any land plant (Sathasivam et al., 2017). Microalgae as aquatic food are getting popular due to their high nutritional values. Microalgae are also having the antioxidant property, the capacity to resist disease as they have antimicrobial (antibacterial, antiviral, and antifungal) activity, and high growth rate (Roy et al., 2014). They play an important role in wastewater remediation, by removing carbon, nitrogen, phosphorus and heavy metals from the environment. Microalgae like Chlorella, Nitzschia, and Scenedesmus are present in the wastewater that is highly polluted, apart from that other species like Cyanophyta cocal, Dactylococcopsis sp., Microspora, etc. used to treat the waste of fish in the water while Teilingia sp., Anabaena sp. Pinnularia sp. and Nitzschia sp. help to treat slaughterhouse wastewater (Salces et al., 2019). Microalgae produce high biomass and have high oil content so, for this, it is used as biofuel production, etc. (Sirakov et al., 2015). Apart from lipids, microalgae are also rich in protein and carbohydrate which is essential for good health, for an example protein or pigments used in the pharmaceutical industry for the treatment of specific diseases while carbohydrate used in the fermentation process and long-chain fatty acids used as health supplements (Chew et al., 2017). Figure 1 elaborated the diverse application of microalgae.

Prawn industries have also become very popular all over the world. Its high productivity has become a major aim and goal to improve its production. By modulating aquafeed, the aim is to improve the growth of prawns, their quality and their successful production and survival has become major interest among the researchers and for that microalgae play a major role to feed the aquatic animals (Li et al., 2015). So, aquaculture will go to become the main interest of focus by industry to facilitate the aquatic products (Han et al., 2019). Another application of microalgae is that they are used as immunostimulants. They improve the immune system and the survival rate of larvae. It is reported that in Rohu fish, Euglena viridis work as antibacterial agent against $A$. hydrophila (Shah et al., 2018). Due to their number of application algae is used as food for aquaculture organism and at the same time it is indirectly consumed by other animals, used to kill harmful microorganisms by producing some antimicrobial compounds, also used in biofuel production as it is a renewable resource and replacement of fossil fuel because fossil fuel is limited and expensive and contribute in the greenhouse effect, microalgae balance the nitrogen in the 
environment, they are easily digestible thus it contributes to improving the growth rate of aquatic organisms and also useful to enhance the reproduction of aquatic organisms (Khan et al., 2018). The bioactive compounds derived from cyanobacteria have a broad range of biological activities such as antibacterial, antifungal, antiviral, anti-neoplastic, antifouling, antioxidant, anti-inflammatory, anticoagulant, and anti-enzymatic (Babu et al., 2017). This review elaborates the multifaceted applications of microalgae in aquaculture in aquaculture wastewater remediation, nutritional potential as aquafeed, biofuels, disease control, and other prospects.

\section{Aquaculture Wastewater Treatment Using Microalgae}

Water is one of the natural and important resources to survive on the planet. But by the time water is getting polluted by discharging waste into the water bodies, like an industrial, domestic, dairy, and agricultural waste. Wastewater contains organic (carbohydrates, fats, proteins, and amino acids) and inorganic pollutants (sodium, calcium, potassium, magnesium, chlorine, sulphur, phosphate, bicarbonate, ammonium salts, and heavy metals) (Raouf et al., 2012; Mahmoud et al., 2016a). This needs to be treated before discharging into water bodies (Mahmoud 2020b). A plethora of aquaculture pollutants can be remediated by the unique potential of microalgae (Table 1 ).

Table 1

Aquaculture wastewater remediation via microalgae

\begin{tabular}{|c|c|c|c|}
\hline $\begin{array}{l}\text { Aquaculture } \\
\text { wastewater }\end{array}$ & Microalgae & Advantages & References \\
\hline $\begin{array}{l}\text { Aquaculture } \\
\text { fishery } \\
\text { wastewater }\end{array}$ & $\begin{array}{l}\text { Chlorella } \\
\text { sorokiniana, Ankistrodesmus } \\
\text { falcatus, and Scenedesmus } \\
\text { obliquus }\end{array}$ & $\begin{array}{l}\text { Nutrient removal efficiency was } \\
86.45-98.21 \% \text { for ammonia, } 75.76- \\
80.85 \% \text { for nitrate, } 98.52-100 \% \text { for } \\
\text { phosphate. }\end{array}$ & $\begin{array}{l}\text { Ansari et } \\
\text { al., } 2017\end{array}$ \\
\hline $\begin{array}{l}\text { fishery } \\
\text { wastewater }\end{array}$ & Diatom Synedra sp. & $\begin{array}{l}\text { Nutrient removal efficacy of } \mathrm{NO}_{3}-\mathrm{N} \\
\text { concentration was } 0.01-0.65 \mathrm{mg} / \mathrm{L}\end{array}$ & $\begin{array}{l}\text { Li et al., } \\
2017\end{array}$ \\
\hline $\begin{array}{l}\text { Brackish } \\
\text { shrimp } \\
\text { aquaculture } \\
\text { wastewater }\end{array}$ & Synechococcus sp. & $\begin{array}{l}16.5 \% \text { in } 10 \mathrm{mg} \mathrm{L}-1 \text { ammonia } \\
\text { removal efficiency }\end{array}$ & $\begin{array}{l}\text { Srimongkol } \\
\text { et al., } 2019\end{array}$ \\
\hline $\begin{array}{l}\text { fish and } \\
\text { shrimp in } \\
\text { aquaculture }\end{array}$ & $\begin{array}{l}\text { Chlorella ellipsoidea, } \\
\text { Scenedesmus dimorphus }\end{array}$ & $\begin{array}{l}\text { Improve fish breeding, survival rate } \\
\text { and wastewater treatment }\end{array}$ & $\begin{array}{l}\text { Kim et al., } \\
2019 b\end{array}$ \\
\hline $\begin{array}{l}\text { Saline } \\
\text { salmon } \\
\text { aquaculture } \\
\text { wastewater }\end{array}$ & Chlorella minutissima & $\begin{array}{l}\text { Total nitrogen and phosphorus were } \\
\text { decrease about } 88 \% \text { and } 99 \% \\
\text { respectively }\end{array}$ & $\begin{array}{l}\text { Paw et al., } \\
2019\end{array}$ \\
\hline $\begin{array}{l}\text { Fishery } \\
\text { wastewater } \\
\text { (Mugil } \\
\text { cephalus) }\end{array}$ & $\begin{array}{l}\text { Isochrysis galbana, } \\
\text { Tetraselmis suecica and } \\
\text { Dunaliella tertiolecta }\end{array}$ & $\begin{array}{l}\text { Tetraselmis suecica and Dunaliella } \\
\text { tertiolecta reduce } 90 \% \text { while Isochrysis } \\
\text { galbana remove } 32 \% \text { and } 79 \% \text { of } \\
\text { dissolved inorganic nitrogen and } \\
\text { phosphorus respectively. }\end{array}$ & $\begin{array}{l}\text { Andreotti et } \\
\text { al., } 2017\end{array}$ \\
\hline
\end{tabular}


To rearing fish in aquaculture the water quality is considered one of the major factors. The pollutants or toxic contaminants in aquaculture can be accumulated in fish, crustacean, mollusks, and bivalves, which can become serious problems who consumed these aquatic organisms (Justino et al., 2016). One of the major issues is the overpopulation of fishes that can make the least genetic diversity in water bodies. This low genetic diversity can cause an imbalance of the ecosystem via leading the marine life extinction. Genetic diversity is required for long-standing evolution towards environmental changes. So, aquaculture promotes those species which are exactly needed to grow for consumption without disturbing the natural environment (Healey et al., 2016).

The aquaculture wastewater contains nutrients because of wastes from fish (fish excreta) farming that contain nitrogen and phosphorous, which are harmful to the environment and can cause many serious problems like hypertrophication (Khatoon et al., 2016). Apart from fish excreta, there is another reason of aquaculture water pollution that is traditional methods to feed aquatic animals, the feed is rich in nutrient mainly lipid and protein but this amount left by the aquatic animal which can slowly convert into a soluble form by bacterial activity, thus it can become the reason of oxygen depletion in the water. In addition, harmful algal blooms cause oxygen depletion in the closed aqua ecosystem and can consume oxygen at the same time, producing some toxic elements so; this is a serious problem for the health of aquatic life (Han et al., 2019).

Few parameters are needed to monitor and check the quality of water for fish farming such as biochemical oxygen demand (BOD), nutrients, chemical oxygen demand, and solid wastes. BOD can decrease the level of dissolved oxygen, so it should be remediated from wastewater (Raouf et al., 2012). Physical methods, chemical methods, or biological methods are used but biological methods are considered as an effective way to treat wastewater because of its high efficiency and low cost (Xing et al., 2018; Mahmoud et al., 2016c).

A Report by Longo et al., (2016) suggested for wastewater treatment plant (WWT) where the dissolved oxygen is maintained by aeration technique but in this technique consumption of high electricity are required (Longo et al., 2016). To treat wastewater eco-friendly and less cost-effective techniques are required. To resolve this problem researchers are focusing to treat the wastewater by using the biological method by cultivating microalgae and reduce the excess of nutrients from the wastewater. Water remediation by using microalgae is an effective way because it can convert excess of nutrient which is rich in nitrogen and phosphorous into useful biomass that contains lipid, protein, and carbohydrate. The algal cells use nitrogen for amino acid synthesis and supplemented cellular components. And phosphate is required to form a cell membrane by synthesizing components of DNA, RNA, ATP, and phospholipids (Xing et al., 2018). Thus, excess of nutrient or waste nutrient can become the food for microalgae which is useful to feed aqua animals, for human food, for fuel production, and industrial purposes (Khatoon et al., 2016). The nutrient-rich microalgal biomass is used to feed fishes for their better growth. Microalgae have the potential to remediate approx $70-90 \%$ of nitrate, sulfate, and phosphate from wastewater (Ansari et al., 2019). Effluent that is rich in oxygen, released after wastewater remediation by algae into 
water bodies. For nutrient removal, few species like Chlorella, Scendesmus, and Spirullina were used (Narasimhan et al., 2010).

Rong et al. demonstrated that the sea cucumber was in demand as it has nutritional value like good protein production and increase the nutritional value of human diet but it produces a huge amount of waste in aquaculture that rich in phosphorus and nitrogen. And to overcome these problems, microalgae Nitzschia $s p$. was used in aquaculture wastewater remediation (Xing et al., 2018).

\section{Microalgae As Biofuel Resource}

As industries are increasing rapidly, the requirement of sustainable energy sources is urgent because the availability of fossil fuel is very limited and depleting rapidly. Using fossil fuel or petroleum-based fuel is hazardous as it is contributing to global warming and release toxic gases into the environment.

Renewable energy sources as biofuel and biogas are better replacement of fossil fuels (Amit et al., 2018). Reported that Botryococcus sp. contain half of the long-chain hydrocarbons of the total dry mass. Many researchers are focusing on improving the production of algal strains for biofuel production by modifying their genetic (Hannon et al., 2011). Many countries are promoting and performing sustainable energy sources like biofuel and biogas. These renewable resources can overcome the problem because it is less expensive than fossil fuel and also more lubricate (Amit et al., 2018).

Biofuel is eco-friendly due to its lower release of $\mathrm{CO}_{2}$ or $\mathrm{CO}$ and sulfur content (Sathasivan et al., 2014b). But the biofuel (biodiesel and bioethanol) consumption is also depending on the sources of it. Biofuel obtains from fermented sugar and oleaginous plants need more energy and arable land which is limited and cost-effective.

Using microalgae are very effective way as sources of renewable biofuel because of its number of application and do not need farming land, they can grow in very less amount of water or area, required nutrient, and high $\mathrm{CO}_{2}$ mitigation rate. Biodiesel production by using microalgae is one of the best ways as it has high oil production because of high lipid content and it can be cultivated or manage easily (Amit et al., 2018). And it is known that microalgae can produce more than $60 \%$ of oil content by dry weight biomass.

In microalgae, lipids are crucial metabolites and important for the growth of aquatic organisms. The microalgal lipids retain both essential and nonessential fatty acids (Ansari et al., 2019). Microalgal species and their growth condition determined the types of lipid such as saturated fatty acids, triacylglycerols, and polyunsaturated fatty acids, etc. So, for biofuel production, the selection of oilsecreting, specific microalgal species are required (Chabukdhara et al., 2017). For the lipid extraction from microalgae, high temperature and use of organic solvents (ethanol, acetone) are required and numerous techniques are used for lipid extraction such as solvent extraction, ultrasonic extraction, and microwave assisted extraction (Chew et al., 2017). 


\subsection{Cultivation of algae}

Microalgae are fast-growing organisms that can grow in terrestrial to the aquatic environment. To culture, the microalgae, the environment where they grow or survive (water) should be rich in nitrate, phosphate, vitamins, and trace element (major nutrients are phosphorus and nitrogen) but in the case of diatom including all the nutrients, one major component i.e. silica also required. (Marella et al., 2020; Zullaikah et al., 2019). Microalgae can reproduce fast in a liquid medium and simple nutrients are required for that as mentioned above. Biomass production can improve by changing the culture conditions as in chlorella, if there is a deficiency of nitrogen content then their biomass rich in lipids by $85 \%$ (Guedes et al., 2015). To grow microalgae in any large area of land, herbicides, pesticide and a maximum amount of water do not require, while it can be grown in wastewater such as domestic wastewater, industrial wastewater, palm oil milling effluents, or sewage wastewater and aquaculture wastewater (Tan et al., 2020b). The required media for all algal or microalgal species is different such as freshwater green algae and blue-green algae are required BG-11 media to grow, for marine algae and diatoms $F / 2$ media is required while eukaryotic green algae and cyanobacteria required ASN-III and Walne media (Aishvarya et al., 2015).

Microalgae can be cultured by using a number of techniques. To culture microalgae, adequate light, temperature, $\mathrm{pH}$, and less contaminated area are required. So, it can be grown in an open pond and closed pond systems (photobioreactors) (Tan et al., 2020b).

\subsection{Downstream processing of biofuel}

Microalgal biomass is required to convert into biodiesel where cultivation, harvesting, oil extraction, and conversion of lipid into the biofuel process are required (Fig. 2). The downstream process cost approx. $60 \%$ of the total biodiesel production. The oil extraction process from dried biomass needs several techniques like cell rupture via ultrasound, autoclave, bead milling, and homogenization. Chemical and biological treatment is needed to break the cell wall using organic solvents, acids, and enzymes. In physical treatments, freeze-thawing and osmotic shock are used to extract oil. Once the oil is extracted, the transesterification process in methanol was done for biodiesel production (Kim et al., 2013a). Reported that the downstream processing depends on the microalgal cell wall, like the cell wall of red algae Cyanidioschyzon merolae can be easily broken to extract cell components, these algae normally found in hot spring season in a metal-rich condition. In contrast Scenedesmus sp. that has multilayer cell wall structure is highly resistant towards biological and chemical disruption (Yew et al., 2019).

\section{Microalgae As Aqua Feed}

Fishmeal is the source of aquaculture feed that is rich in protein, fatty acids, vitamins, and minerals. Fishmeal is the brown flour that is procured from the whole fish by cooking, drying, and pressing it. But fishmeal is limited and cost-effective that can rise up to 30 to $60 \%$. So, these problems need to solve and need to find out a new source of nutritious fish food. 
Production of algae is the best source and inexpensive source for aquafeed and better replacement of fishmeal that can save about $40 \%$ of feeding cost than fishmeal which cost is known two-third of aquaculture costs [37]. Algae or microalgae are important for aquatic life because they are eaten by zooplanktons and basic in the aquaculture food chain. The use of algae is considered as the main ingredient for fish in aquafeed and it has been reported that a very few amounts of algae are sufficient for the fish diet that gives better growth rate, feed utilization efficiency, intestinal microbiota, physiological activity, give strength to fight against diseases, and capacity to hold the protein in the winter season to decrease the chance of feed intake and control the stress response (Norambuena et al., 2015). The nutritional value of microalgae depends on various factors that are cell size and shape, digestibility, biochemical contents, and animal feeding requirements of microalgae (Guedes et al., 2015). Microalgae are considered a rich source of nutrition as a report by Alberto that microalgae are the source of carbohydrate, protein, lipid, and dietary fiber (Niccolai et al., 2019). It is reported that microalgae have 30$40 \%$ protein, $10-20 \%$ lipids, and $5-15 \%$ carbohydrate in late log phase (Shah et al., 2018). All stages of bivalve mollusk and the larval or juvenile stages of fish and crustacean species eat the microalgae (Brown et al., 2013). The nutritional value of microalgae is varying from species to species; some may be rich in carbohydrates while some of them are rich in protein, vitamins, or lipids (Table 2).

Table 2

Microalgae as feed for aquaculture organism

Microalgae

Chaetoceros calcitrans, Nannochloris maculate, and Tetraselmis chuii

A. platensis, P. tricornutum

Coccomyxa onubensis sp.

Chlorella vulgaris

Asterarcys quadricellulare Chlorella vilgaris

\section{Advantages of microalgae as feed}

Protein and lipid content were higher in $N$. maculate and $T$. chuii beneficial as live feed utilization for aquaculture

Protein content was estimated $63.9 \pm 1,38.8 \pm 0.11$ and carbohydrate content $12.8 \pm 0.21,11.0 \pm 0.70$ (\% of algal powder).

Protein, lipid, carbohydrate and dietary fiber content was found $44.6 \%, 5.4 \%, 24.8 \%$ and $15.73 \%$, respectively

protein (44.60\%), dietary fiber (15.73\%), carbohydrate content (24.8\%) lipid content (5.4\%)

$20.0 \pm 0.3 \%$ of lipid and $36.6 \pm 2.0 \%$ of carbohydrate content found in $A$. quadricellulare

C. vulgaris is used to feed catfish Clarias gariepinus having lipid $24.40 \pm 0.09$ carbohydrate $12.09 \pm 3.17$ and protein $54.65 \pm 0.07$

\section{References}

Khatoon et al., 2016

Niccolai et al., 2019

Navarro et al., 2016 and protein $54.65 \pm 0.07$

Among the other microalgae, Spirulina is used as fish feed which is known to have better growth. It has been predicted that the demand for fish production will be increased day by day so that algae or microalgae will be high on demand for fish food, thus, it will provide a great amount to the algal and aquaculture industry. And for that high production of the bioactive compound is required that can get from selective strain or by genetic modification while some of the chemicals as metabolites can 
modulate the cellular metabolism that can activate the high yield production of bioactive compounds for as example epigallocatechin gallate and cyclin-dependent kinase 2 inhibitors can trigger the production of intracellular lipids in Nannocloropsis and Phaeodactylum tricornutum (Talero et al., 2015). Figure 3 elaborates the diverse applications of algal biomass.

\subsection{Protein}

Protein is the major metabolite of microalgal biomass, and their productivity depends on several factors such as different species, culture conditions (temperature, $\mathrm{pH}$, and light) and nutritional value, and environmental factors. Nitrogen plays an important role in increases the yield of protein. Reported that the microalgae show higher protein yield when it has grown in high nitrogen concentration (Ansari et al., 2019).

Fishmeal is used in the feed that has high protein content including all required amino acids. In fish meal, plant (crop) protein is usually used, in which few of amino acids are not present like lysine, methionine, threonine, etc. and it was reported that in microalgae almost all required amino acids are present [Henry 2013]. In fish meal adequate amount of amino acid (lysine, methionine, etc.) is required so, microalgae have been found to have all essential amino acids (Chrapusta et al., 2017). The Amino acid varies from species to species, like marine algae have fewer sulfur-containing amino acids than freshwater microalgae (Ansari et al., 2019). Except for fish meal, microalgae (Nostoc, Arthrospira, and Aphanizomenon) are also a good source of protein and other nutrients for the human diet (Caporgno et al., 2018). Microalgae like $S$. platensis and $C$. vulgaris can produce a high amount of protein content, this quality makes them a good source of food for aquatic life. There is a marine product known as Mycosporine like amino acid or MAAs, this is the secondary metabolite. The molecular weight of MAAs is $<400 \mathrm{Da}$. It protects against UV radiation (Chrapusta et al., 2017). MAAs produced by several organisms and it also produced by microalgae including Chlamydomonas nivalis and other green algal species. This can be trigger by UV light exposure. It is used for commercial purposes like sunscreen and other skincare products because it protects from UV light and also used as anti-aging products.

\subsection{Carbohydrate}

The carbohydrate content is less than protein and lipids but it is known as the main substrate for various biofuel productions such as bioethanol, biohydrogen, etc. Photosynthetic microalgae convert solar energy into chemical energy via several complex reactions called photosynthesis. These two photosynthetic reactions are including light and dark reactions. In the light reaction chlorophyll pigment capture the solar energy and used to break the water molecules into electron, proton and oxygen and then this proton and electron produce energy transporter i.e. NADPH and ATP while in dark reaction, the NADPH, and ATP are used to reduce carbon dioxide to carbohydrate via Calvin cycle.

Carbohydrate production in algae, fulfill two requirements; first in cell wall as a structural component and second for storage purpose in cell. As the storage component, carbohydrate gives the required energy 
during metabolism. The storage compounds (carbohydrates, protein) in algae helps in growth adjustment when the environmental conditions change.

The carbohydrate is species-specific such as cyanobacteria synthesize glycogen, red algae synthesize floridean starch and green algae synthesize amylopectin-like polysaccharides (starch), etc. (Markou et al., 2012; Khan et al., 2018). Microalgal Polysaccharides can adjust the immune system and inflammatory reactions, so, this quality makes them a more attractive source as biologically active molecules for example used in cosmetics, as natural curative agents, and used in food products.

\subsection{Vitamins and minerals}

Microalgae are also rich in vitamins and minerals that are necessary organic micronutrients. In microalgae, vitamin production depends on the presence of nitrogen. At a low concentration of nitrogen, cyanobacteria produce the least vitamin B 12. So, the concentration of nitrogen in the culture medium affects the content of vitamins. For aquaculture animals, vitamin riboflavin is important that is found in microalgae (Chew et al., 2017). Chlorella and Spirulina species (beta carotene and B 12) have more vitamins than plants and animals. Most of the microalgae contain an active form of vitamin $E$ i.e. $\alpha-/ \beta-$ tocotrienol or $\alpha-/ \beta$-tocopherol (vitamin $\mathrm{E}$ ) at a very high concentration that has antioxidant property (Guedes et al., 2015). And vitamin $\mathrm{E}$ is also used to treat heart and eye disorders, Alzheimer's disease, and cancer. Vitamin $\mathrm{C}$ is stored by a few algal species that have antioxidant activity (Sathasivam et al., 2017a).

The algae have the potential to replace inorganic salt with vitamins and minerals. Vitamins cannot be directly synthesizing in sufficient amounts only it can be obtained from the diet. If there is deficiency of vitamins then it can lead to several diseases such as beriberi (deficiency of vitamin B), pellagra (niacin), and scurvy (ascorbic acid, vitamin C). Ascorbic acid is found to (Vitamin C) has maximum variation among all vitamins because it is heat sensitive. Algal food such as sea spaghetti (Himanthalia elongata), Gracilaria changii, and laver (Porphyra umbilicalis) contain more Vitamin C than any vegetables (Wells et al., 2017).

\subsection{Pigments}

Microalgae are highly exposed to oxygen and radical stress due to their phototrophic nature. As they produce valuable bioactive compounds that have various important roles like protecting against oxidative and radical stressors (Tan et al., 2018a). Pigments are one of the important compounds that have number of applications like antibacterial and antioxidant activities (Fig. 4).

Phycocyanin pigment secreted by Spirulina help treat damage bone marrow stem cell by controlling the production of White blood cell (WBC). The astaxanthin which is a keto-carotenoid synthesized from microalgae is reported to essential for the survival and growth of shrimps, salmon, and trout. Astaxanthin protects the algae from the damage of UV radiation and photooxidation of polyunsaturated astaxanthin. Nguyen et al. reported that the algae which synthesized this astaxanthin are Haematococcus pluvialis, Chlorella zofingiensis, and Chlorococcum sp., the red yeast Phaffia rhodozyma (Nguyen 2013). 
Carotenoids are a class of natural fat-soluble pigments found principally in algae where they play a critical role in the photosynthetic process. In human beings, carotenoids can serve several important functions. The most widely studied and well-understood nutritional role for carotenoids is their provitamin A activity. Carotenoids are found to be powerful antioxidants. Beta-carotene is an essential carotenoid as it is the form of provitamin $A$ and is used in many food products. $\beta$-Carotene is a natural pigment derived from green algae, is used as a yellow-orange food coloring agent and may help prevent certain types of cancers. It is reported that few species of Dunaliella produce beta-carotene at a very high amount under extreme temperature, high light intensity and high salinity; it has very effective values as it is used as anticancerous and as antioxidants (Sathasivam et al., 2012c). For the production of beta carotene, proper environmental conditions are required. There are cis and trans isomers of beta carotene, where cis isomer of beta carotene has effective role as it protects the cell from oxidative damage (Sathasivam et al., 2017a).

\subsection{Omega 3 fatty acids}

The Omega-3 fatty acid is one of the most important fatty acids that have health benefits because of its anti-inflammatory, anti-blood clotting property as well as help in regulating blood pressure and diabetes. Eicosapentaenoic acid (EPA) and docosahexaenoic acid (DHA) are the two main types of omega-3 fatty acids. Algae are the novel source of omega-3 fatty acids (Ji et al., 2015). It is reported that at the logarithmic phase, phospholipids are high in microalgae while at the stationary phase they are rich in triacylglycerols. Eicosapentaenoic acid (EPA), arachidonic acid (AA), docosahexaenoic acid (DHA), and alinoleic acid (ALA), are reported to essential for larval growth. Omega-3 fatty acid or polyunsaturated omega-3 fatty acid (PUFA) is secreted by microalgae at very high amount (Han et al., 2019). PUFA regulates the membrane fluidity, electron or Oxygen transport, and thermal adaptation of cellular and tissue metabolism.

It is known that different species are rich in a different amount of Omega-3 fatty acid or polyunsaturated omega-3 fatty acid (PUFA) like docosahexaenoic acid (DHA) and Eicosapentaenoic acid (EPA). Diatom Bacillariophyceae and Chrysophyceae are rich in EPA and DHA while more amount of DHA found in Dinophyceae, Prymnesiophyceae, and Euglenophyceae whereas EPA found at a very high amount in Cryptophyceae, Prasinophyceae, Rhodophyceae, Xanthophyceae, and Glaucophyceae (Shah et al., 2018).

\section{Microalgae As Biocontrol Agents}

The Aquaculture industry is the fastest growing industry and a report suggested that in 2014, world aquaculture production earned approx. 160 billion from finfish, mollusks, and other aquatic animals but there is a problem to get infection of aquaculture animal from bacteria, virus, and fungus. Examples of infectious diseases in shrimps from viral pathogens are the White Spot Syndrome Diseases (WSSD), Yellow Head Disease (YHD) and the bacterial infection in shrimps is Early Mortality Syndrome (EMS) (Charoonnart et al., 2018). Table 3 highlights the antimicrobial potential of microalgae. 
Table 3

Antimicrobial activity by Microalgae against targeted bacteria

Chlorella minutissima, Tetraselmis chui, Nannochloropsis sp., Arthrospira platensis and Isochrysis sp.
Microalgae

Targeted pathogens

Vibrio parahaemolyticus, $V$. anguillarum, $V$. splendidus, $V$.

scophthalmi, $V$. alginolyticus and $V$. lentus

Vibrio alginolyticus, $V$. campbellii, and V. harveyi

Cardenas

Nitzschia laevis, Nitzschia frustulum, Navicula incerta, e Navicula biskanterae and Navicula cf. incerta

Amphora sp.
References

Kokou et al., 2012 et al., 2017

Boukhris
Bacillus cereus, Bacillus subtilis, Micrococcus luteus, Staphylococcus aureus, Klebsiella pneumoniae and almonella enterica

Bacillus subtilis, Staphylococcus aureus and Microccocus luteus et al., 2017

Saavedra et al., 2010 sp., Amphiprora paludosa, Porphyridium cruentum, Chaetoceros muelleri and Dunaliella tertiolecta

Skeletonema costatum

Listonella anguillarum, Aeromonas sp., Serratia liquefasciens, Vibrio sp. and Naviner et Yersinia ruckeri

Anabaena variabilis

Rhizopus stolonifer and Aspergillus niger

Tiwari et al., 2013a

Synechococus elongates and Anabaena variables

Klebsiella sp., Enterococcus sp. and E. coli

Tiwari et al., 2013b

\subsection{Bacterial disease and its treatment by microalgae}

Bacterial pathogens are considered the main cause of infection in fishes and most usual bacterial pathogen species belong to Aeromonas, Pseudomonas, and Vibrio genus (Charoonnart et al., 2018). Bacterial pathogens can cause serious mass mortality in aquaculture, by infecting the aquaculture organism such as disease in finfish mainly caused by Aeromonas sp. and Pseudomonas sp. can induce hemorrhages while Vibrio sp. triggers vibriosis in marine fish. Many species of vibrio can spread disease and can involve in massive mortalities in bivalves and shrimps. To control the bacterial disease antibiotic used to save aquatic organisms but bacteria have developed antibiotic resistance against existing antibiotics. And there are number of side effect of synthetic antibiotics. So, there is a solution by using natural sources that have no or fewer side effects and are available to develop antibacterial activity against pathogenic bacteria. Microalgae are one of them, which have antibacterial properties.

Microalgae are available all around the world and they are consumed and exposed to disease-causing microbes such as bacteria, fungi, and virus. So, to protect themselves from the pathogens they need to develop a defense mechanism against these pathogens. Several studies elucidated that microalgae or algae posse antioxidant, anti-inflammatory, and antimicrobial properties (Fig. 5). The microalgae or algae which live in an environment where the bacterial population is dense can synthesized the antibacterial 
metabolites to kill the bacteria than those who live in a bacteria-free environment. The antimicrobial property of microalgae is depending on the species, their culture condition and their growth conditions. The Vibrio species are the target pathogen to test the antibacterial effect of microalgae. Microalgae, Tetraselmis suecia exhibit antibacterial effect against Vibrio alginolyticus, vibrio anguillarum, Vibrio parahaemolyticus and Vibrio vulnificus.

The antibacterial compound in microalgae are considered long chain polyunsaturated fatty acids (LCPUFA) like eicosapentaenoic acid (EPA), sterol which is active against gram-positive and gram-negative bacteria. So, when aquatic animals eat microalgae, then the chances of the infection get reduced. Fatty acid from diatom Phaeodactylum triconutum found to have antibacterial activity against Methicillinresistant Staphylococcus aureus (MRSA), for that three unsaturated fatty acids are found to involve for antibacterial activity. The three unsaturated fatty acids are:
I. Eicosatetraenoic acid (EPA)
II. Palmitolic acid (PA)
III. Hexadecatrienoic acid (HTA)

It was predicted that the cellular membrane of bacteria was first targeted to kill it. Fatty acids damage the bacterial cell membrane; resulting in cell leakage and cellular respiration get reduced (Falaise et al., 2016). Phenolic compounds are secondary metabolites that have antimicrobial activity by changing the cell permeability and damage the macromolecules of microbes (Perez et al., 2016).

Antibacterial activity was tested against fish pathogen Aeromonas by using diatom species Skeletonema, Thalassiosira, and Chaetoceros where it showed growth inhibition of bacteria (Fig. 6). The clear zone of inhibition was observed and diatom Thalassiosira inhibiting maximum growth of Aeromonas (Bhattacharjya et al., 2020).

\subsection{Viral disease}

Diseases in fish also caused by viral pathogens, on that number of the study was done, one of the reports suggested that the disease in fish caused by viruses in which betanodavirus like nervous necrosis virus (NNV), Megalocyticvirus such as infectious spleen and kidney necrosis virus (ISKNV), and red sea bream iridovirus (RSIV) are included (Charoonnart et al., 2018).

Treatment by antibiotics only targets the bacterial infection it does not protect against viral infection. So, to overcome this problem vaccines are developed which is efficient against bacterial pathogens as well as viral pathogens but there is also a challenge to inject the vaccine into the intramuscular which can hurt the fishes and aquaculture animals. This vaccine needs to store at a cold temperature which is very expensive. So instead of injecting the vaccine there was found another method that is direct spray the 
vaccine but doing this method needs more amount of vaccine and it can become a stressful situation for the fish (Charoonnart et al., 2018). Many compounds are found in algae, bacteria and other marine organisms and few of them have shown the antiviral property. Antiviral property from Gelidium cartilagenium algae exhibited protection from influenza $B$ and mumps viruses to embryonated eggs. Cyanobacteria are considered a better source of the antiviral compound. A compound sulphated polysaccharide from cyanobacteria is considered to have antiviral efficacy against human immunodeficiency virus type 1 (HIV-1) and herpes simplex virus type 1 (HSV-1).

Previous studies showed that many antibiotic compounds have been isolated from the cyanobacterial and microalgal extracts, observed that cyanobacteria have antiviral and antineoplastic compounds (Falaise et al., 2016).

Terpenes are one of the bioactive compounds that are produced by algae. Terpenes such as diterpene neophytadiene, sesquiterpenes cartilagineol, obtusol, and elatol isolate from seaweed have antiviral property (Perez et al., 2016).

\subsection{Antifungal activity}

Apart from the bacterial and viral disease, fungal disease in fishes is the major concern to get over it. Few examples of fungi that caused disease in fishes are Aspergillus terruse, Aspergillus clivatus; Alternaria spp, Saprolegnia parasitic, Saprolegnial apponica, Saprolegnia ferax, and Saprolegnia hypogyna. The increasing problem of fungal infections prompted the search for newer and safer agents to fight against fungal infections in fishes (Patel et al., 2018). Instead of chemical treatment microalgae are found to be the best way to treat fungal infection. Cyanobacteria were found to have antifungal property against fungal strains: Aspergillus niger, Aspergillus fumigates, Trichophyton rubrum, and Macrophomina sp. Cyanobacteria produce intracellular and extracellular metabolites that have antibacterial, antifungal, antiviral, and anticancer potential (Babu et al., 2017).

\section{Outlook For Circular Bioeconomy}

The circular economy is ideal of production and consumption in which the idea of material is reused, repaired, and recycled as much as possible. Algae are beneficial for circular bioeconomy as they do not require very compound media; they only just need light, basic nutrients to grow. Microalgae can be cultivated in wastewater like sewage wastewater, aquaculture wastewater, etc. as a nutrient (Abidizadegan, 2020).

Amongst that wastage of food is generating a huge amount of bio-waste all around the world. And this may be generated during manufacturing, handling, packing, and consumption. Wastage of food is the big problem; this food contains carbohydrates, lipid, and proteins that can degrade into a simple form such as glucose, fatty acid, and amino acid respectively. To manage the wastage of food, the waste food can be converted into algal bio-fertilizer, biodiesel, and other useful things by bioprocessing. And food waste and wastewater are the best way to utilize to cultivate algae that work as algal nutrients. When algae or 
microalgae grow in the wastewater it gives a maximum quantity of lipids and biomass. Reported that Chlorella pyrenoidosa and Schizochytrium mangrovei when cultivated in canteen waste like vegetable, rice, and meat, etc. produce more lipid while Chlorella sorokiniana give approx. $23 \%$ of intracellular lipid when it cultured in food and municipal wastewater. So, algae produce large number of life supportable bioproducts. As microalgae can be cultivate in wastewater and waste food as a source of nutrient that is the solution of circular bioeconomy over environmental waste and agriculture by lowering the greenhouse gas emission, deforestation, and nutrient pollution (Dahiya et al., 2018).

Microalgae are the primary producer in the food chain for aquatic animals that are rich in nutrients. The carbohydrates, protein, and lipid content are dependent on the algal species and also produce hormones, pigments, and secondary metabolites that work as immunostimulants, anti-inflammatory, antimicrobial, antioxidant for aquatic organisms. The microalgal production did not require any arable land, excess of water. Microalgae convert atmospheric carbon dioxide into high nutrient products. This provides better circular bioeconomy via general circular aquaculture industry (Yarnold et al., 2019).

\section{Conclusions}

The progress of aquaculture industry is greatly influenced by the significant challenges like the accessibility of resources which are natural in origin and the environmental impact. The sustainable utilization of resources, high productivity and good profit can accelerate this industry and help in achieving the SDG targets wherein the objectives can help in eradication of poverty(SDG 1), providing adequate nutrition (SDG 2) and aid in substantial growth (SDG 8) for a better tomorrow. In this regard microalgae can play a lead role in the improvisation of feed quality and enhanced feed utilization promoting better fish health concomitant with utilization of minimal ecofriendly resources.

\section{Declarations}

\section{Acknowledgment}

We are thankful to Department of Biotechnology, Ministry of Science and Technology for research funding (BT/PR15650/AAQ/3/815/2016).

The authors declare no conflict of interest.

\section{Author Credit}

Formal analysis and investigation, writing - original draft preparation: Bharti Mishra; Writing - review and editing: Alaa El Din Mahmoud; Conceptualization, Funding acquisition, Resources, Supervision: Archana Tiwari

\section{References}


1. Aishvarya V, Jena J, Pradhan N, Panda PK, and Sukla LB (2015) Microalgae: Cultivation and Application. Environ. Microbial Biotechnol., Soil Biology. 45:289-311. DOI: 10.1007/978-3-319-190181_15.

2. Amit, Ghosh UK (2018) An approach for phycoremediation of different wastewaters and biodiesel production using microalgae. Environ Sci Pollut Res 25:18673-18681. https://doi.org/10.1007/s11356-018-1967-5.

3. Andreotti V, Chindris A, Brundu G, Vallainc D, Francavilla M, Garcia J (2017) Bioremediation of aquaculture wastewater from Mugil cephalus (Linnaeus, 1758) with different microalgae species. Chem Ecol 33(8):750-761. DOI: 10.1080/02757540.2017.1378351.

4. Ansari FA, Singh P, Guldhe A, Bux F (2017) Microalgal cultivation using aquaculture wastewater: Integrated biomass generation and nutrient remediation. Algal Res 21:169-177. http://dx.doi.org/10.1016/j.algal.2016.11.0152.

5. Ansari FA, Gupta SK (2019) Microalgae: A Biorefinary Approach to the Treatment of Aquaculture Wastewater. In book: Application of Microalgae in Wastewater Treatment, Springer Nature Switzerland AG 201969 S. K. Gupta, F. Bux (eds.), DOI: 1007/978-3-030-13909-4_4.

6. Abidizadegan M (2020) Algae in circular economy. Potent algae. https://blogs.helsinki.fi/potentalgae/2020/05/21/circular-economy/.

7. Babu RM, Malathi T, Rao BD (2017) Antifungal activity of selected cyanobacteria against fungal pathogens. Int J Pharm Biol Sci 7(4):207-213.

8. Brown MR, Blackburn SI (2013) Live microalgae as feeds in aquaculture hatcheries. Advances in Aquaculture Hatchery Technology. 117-156. DOI:1533/9780857097460.1.117.

9. Bhattacharjya R, Marella TK, Tiwari A, Saxena A, Singh PK, Mishra B (2020) Bioprospecting of marine diatoms Thalassiosira, Skeletonema and Chaetoceros for lipids and other value-added products. 318, https://doi.org/10.1016/j.biortech.2020.124073.

10. Bhavsar DO, Pandya HA, Jasrai YT (2016) Aquaculture and Environmental Pollution: A Review Work. IJSRSET Sci Technol 2(1):40-45.

11. Boukhris S, Athmouni K, Mnif IH, Elleuch RS, Ayadi H, Nasri M, Kamoun AS (2017) The Potential of a Brown Microalga Cultivated in High Salt Medium for the Production of High-Value Compounds. https://doi.org/10.1155/2017/4018562.

12. Caporgno MP, Mathys A (2018) Trends in Microalgae Incorporation into Innovative Food Products with Potential Health Benefits. Front Nutr 5:58. DOI: 10.3389/fnut.2018.00058.

13. Cardenas M, Saavedra S (2017) Inhibitory effect of benthic diatom species on three aquaculture pathogenic Vibrios. Algal Res 27(27):131-137. DOI: 1016/j.algal.2017.09.004

14. Chabukdhara M, Gupta SK, Gogoi M (2017) Phycoremediation of Heavy Metals Coupled with Generation of Bioenergy. In book: Algal Biofuels. DOI 10.1007/978-3-319-51010-1_9.

15. Charoonnart P, Purton S, Saksmerprome V (2018) Applications of Microalgal Biotechnology for Disease Control in Aquaculture. Biology (Basel) 7(2), 24. DOI: 10.3390/biology7020024. 
16. Chew KW, Yap JY, Show PL, Suan NH, Juan JC, Ling TC, Lee DJ, Chang JS (2017) Microalgae biorefinery: high value products perspectives. Bioresour Technol 229:53-62. DOI: http://dx.doi.org/10.1016/j.biortech.2017.01.006.

17. Chrapusta E, Kaminski A, Duchnik K, Bober B, Adamski M, Bialczyk J (2017) Mycosporine-Like Amino Acids: Potential Health and Beauty Ingredients. Mar drugs 15 (10):326. doi:10.3390/md15100326.

18. Dahiya S, Kumar N, Sravan JS, Chatterjee S, Sarkar O, Mohan SV (2018) Food waste biorefinery: Sustainable strategy for circular bioeconomy. Bioresour Technol 248:2-12. DOI: http://dx.doi.org/10.1016/j.biortech.2017.07.176.

19. Enyidi U (2017) Chlorella vulgaris as Protein Source in the Diets of African Catfish Clarias gariepinus. Fishes 2(17). DOI: 10.3390/fishes2040017.

20. Falaise C, Francois C, Travers MA, Morga B, Haure J, Tremblay R, Turcotte F, Pastto P, Gastineau R, Hardvillier Y, Leignel V, Mouget JL (2016) Antimicrobial Compounds from Eukaryotic Microalgae against Human Pathogens and Diseases in Aquaculture. Mar drugs 14(9):159. DOI: $10.3390 / \mathrm{md} 14090159$.

21. Guedes AC, Pinto IS, Malcata FX (2015) Application of Microalgae Protein to Aquafeed. Handbook of Marine Microalgae Biotechnol Adv 93-125. DOI:10.1016/b978-0-12-800776-1.00008-x.

22. Halima NB (2018) Why is it important to use algae in aquaculture? J Biochem Biotech 1(1):11-13. DOI: 35841/Biochemistry-Biotechnology.1000106.

23. Han P, Lu Q, Fan L, and Zhou W (2019) A Review on the Use of Microalgae for Sustainable Aquaculture. Appl Sci 9(11): 2377. https://doi.org/10.3390/app9112377.

24. Hannon M, Gimpel J, Tran M, Rasala B, Mayfield S (2011) Biofuels from algae: challenges and potential. Biofuels 1(5):763-784. DOI: 10.4155/bfs.10.44.

25. Healey B, Dell'Erba W, Leavitt K (2016) Aquaculture and its impact on the environment. https://blogs.umass.edu/natsci397a-eross/aquaculture-and-its-impact-on-the-environment/ .

26. Henry EC (2012) The use of algae in fish feeds as alternatives to fishmeal. Aquacuture https://en.engormix.com/aquaculture/articles/the-use-algae-fish-t35812.htm

27. Ji XJ, Ren LJ, Huang H (2015) Omega-3 Biotechnology: A Green and Sustainable Process for Omega3 Fatty Acids Production. Front Bioeng Biotechnol 3(158). DOI: 3389/fbioe.2015.00158.

28. Justino CIL, Duarte KR, Freitas AC, Panteleitchou TSL, Duarte AC, Santos TAPR (2016) Contaminants in aquaculture: Overview of analytical techniques for their determination. TrAC 80:293-310. http://dx.doi.org/10.1016/j.trac.2015.07.014.

29. Khan MI, Shin JH, Kim JD (2018) The promising future of microalgae: current status, challenges, and optimization of a sustainable and renewable industry for biofuels, feed, and other products. Microb Cell Fact 17: 36. DOI: 1186/s12934-018-0879-x.

30. Khatoon H, Banerjee S, Syakir MS, Noordin NBM, Bolong AMA, Endut A (2016) Re-use of aquaculture wastewater in cultivating microalgae as live feed for aquaculture organisms. Desalin water treat 57(60):29295-29302. DOI: 1080/19443994.2016.1156030. 
31. Kim J, Yoo G, Lee H, Lim J, Kim K, Kim CW, Park MS, Yang JW (2013a) Methods of downstream processing for the production of biodiesel from microalgae. Biotechnol Adv 31(6):862-876. DOI: 10.1016/j.biotechadv.2013.04.006.

32. Kim K, Jung JY, Han HS (2019b) Utilization of Microalgae in Aquaculture System: Biological Wastewater treatment. Emerg sci j 3(4). DOI: 28991/esj-2019-01183.

33. Kokou F, Makridis P, Kentouri M, Divanach P (2012) Antibacterial activity in microalgae cultures. Aquac Res 43(10):1520-1527. DOI: 1111/j.1365-2109.2011.02955.x.

34. Li Y, Xiao G, Mangott A, Kent M, Pirozzi I (2015a) Nutrient efficacy of microalgae as aquafeed additives for the adult black tiger prawn, Penaeus monodon. Aquac Res 11:1-11.

DOI:10.1111/are.12815.

35. Li XL, Marella TK, Taov, Peng L, Song CF, Dai L, Tiwari A, Li G (2017b) A novel growth method for diatom algae in aquaculture waste water for natural food development and nutrient removal. Water Sci Technol 75(12):2777-2783. DOI: 10.2166/wst.2017.156.

36. Longo S, Antoni BM, Bongards M, Chaparro A, Cronrath A, Fatone F, Lema JM, Iglesias MM, Soares A, Hospido A (2016) Monitoring and diagnosis of energy consumption in wastewater treatment plants. A state of the art and proposals for improvement. Appl Energy 179:1251-1268. https://doi.org/10.1016/j.apenergy.2016.07.043.

37. Mahmoud AED, Fawzy M, Radwan A (2016a) Optimization of Cadmium (CD (2+)) removal from aqueous solutions by novel biosorbent. Int J Phytoremediation 18(6):619-625. DOI: 10.1080/15226514.2015.1086305.

38. Mahmoud AED (2020b) Graphene-based nanomaterials for the removal of organic pollutants: Insights into linear versus nonlinear mathematical models. J Environ Manage 270. DOI: https://doi.org/10.1016/j.jenvman.2020.110911.

39. Mahmoud AED, Fawzy M (2016c) Bio-based Methods for Wastewater Treatment: Green Sorbents. In book: Springer International Publishing Switzerland, A.A. Ansari et al. (eds.), Phytoremediation. DOI 10.1007/978-3-319-40148-5_7.

40. Marella TK, Pacheco IYL, Saldivar RP, Dixit S, Tiwari A (2020) Wealth from waste: Diatoms as tools for phycoremediation of wastewater and for obtaining value from the biomass. Sci Total Environ 724, 137960. DOI: https://doi.org/10.1016/j.scitotenv.2020.137960.

41. Markou G, Angelidaki I, Georgakakis D (2012) Microalgal carbohydrates: an overview of the factors influencing carbohydrates production, and of main bioconversion technologies for production of biofuels. Appl Microbiol Biotechnol 96(3):631-645. DOI 10.1007/s00253-012-4398-0.

42. Narasimhan AM (2010) Microalgal bioremediation of nutrients in wastewater and carbon dioxide in flue gas. Masters Theses. 4779. https://scholarsmine.mst.edu/masters_theses/4779.

43. Navarro F, Forjan E, Vazquez M, Montero Z, Bermejo E, Castano MA, Toimil A, Chaguaceda E, Sevillano MAG, Sanchez M, Domínguez MJ, Pasaro R, Garbayo I, Vílchez C, and Vega JM (2016) Microalgae as a safe food source for animals: nutritional characteristics of the acidophilic microalga Coccomyxa onubensis. Food Nutr Res 60(10). DOI: 3402/fnr.v60.30472. 
44. Naviner M, Berge JP, Durand P, Bris HL (1999) Antibacterial activity of the marine diatom Skeletonema costatum against aquacultural pathogens. Aquaculture 174(1-2):15-24. https://doi.org/10.1016/S0044-8486(98)00513-4.

45. Nguyen KD (2013) Astaxanthin: A Comparative Case of Synthetic VS. Natural Production. Chem Biomol Eng. http://trace.tennessee.edu/utk_chembiopubs.

46. Niccolai A, Zittelli GC, Rodolfi L, Biondi N, Tredici MR (2019) Microalgae of interest as food source: Biochemical composition and digestibility. Algal Res 42. https://doi.org/10.1016/j.algal.2019.101617.

47. Norambuena F, Hermon K, Skrzypczyk V, Emery JA, Sharon Y, Beard A, Turchini GM (2015) Algae in Fish Feed: Performances and Fatty Acid Metabolism in Juvenile Atlantic Salmon. Plos one 10(4). https://doi.org/10.1371/journal.pone.0124042

48. Oliveira O, Gianesella S, Silva V, Mata T, Caetano N (2017) Lipid and carbohydrate profile of a microalga isolated from wastewater. Energy Procedia 136:468-47. https://doi.org/10.1016/j.egypro.2017.10.305

49. Patel AS, Patel SJ, Bariya AR, Pata BA, Ghodasara SN (2018) Fungal Diseases of Fish: A Review. J Vet Sci Res 3(3). ISSN: 2474-9222.

50. Paw MH, Koniuszy A, Gałczynska M, Zajac G, Barglowicz JS (2019) Production of Microalgal Biomass Using Aquaculture Wastewater as Growth Medium. Water 12(1):106. DOI:10.3390/w12010106.

51. Perez MJ, Falque E, Dominguez H (2016) Antimicrobial Action of Compounds from Marine Seaweed. Mar Drugs 14(3):52. DOI: 3390/md14030052.

52. Raouf AN, Homaidan AA, Ibraheem IBM (2012) Microalgae and wastewater treatment. Saudi J Biol Sci 19(3):257-275. DOI: 1016/j.sjbs.2012.04.005.

53. Roy SS, Pal R (2014) Microalgae in Aquaculture: A Review with Special References to Nutritional Value and Fish Dietetics. Proc Zool Soc 68:1-8. https://doi.org/10.1007/s12595-013-0089-9.

54. Saavedra MPS, Navarro AL, Sarabia JB (2010) Evaluation of the antibacterial activity of different species of phytoplankton. Rev biol mar oceanogr 45(3):531-536. DOl: http://dx.doi.org/10.4067/S0718-19572010000300019.

55. Salces BM, Riano B, Hernandez D, Gonzalez MCG (2019) Microalgae and Wastewater Treatment: Advantages and Disadvantages. In book: Microalgae Biotechnology for Development of Biofuel and Wastewater Treatment 505-533. DOI: 10.1007/978-981-13-2264-8_20.

56. Sathasivam R, Kermanee P, Roytrakul S, Juntawong N (2012) Isolation and molecular identification of $\beta$-carotene producing strains of Dunaliella salina and Dunaliella bardawil from salt soil samples by using species specific primers and internal transcribed spacer (ITS) primers. Afr J Biotechnol 11(102). DOI: 5897/AJB12.063.

57. Sathasivam R, Radhakrishnan N, Hashem A, Allah EFA (2017) Microalgae metabolites: A rich source for food and medicine. Saudi J Biol Sci 26(4):709-722. DOI: https://doi.org/ 10.1016/j.sjbs.2017.11.003. 
58. Sathasivan R, Hemaiswarya S, Raja R, Juntawong N, Ganesan V, Anabazhagan C, Carvalho IS (2014) Microalgae as an Attractive Source for Biofuel Production. J Environ Sustain 129-157. DOI 10.1007/978-81-322-2056-5_8.

59. Shah MR, Lutzu GA, Alam A, Sarker P, Chowdhury MAK, Parsaeimehr A, Liang Y, Daroch M (2018) Microalgae in aquafeeds for a sustainable aquaculture industry. J Appl Phycol 30:197-213. https://doi.org/10.1007/s10811-017-1234-z.

60. Sirakov I, Velichkova K, Stoyanova S, Staykov Y (2015) The importance of microalgae for aquaculture industry. Review. Int J Fish Aquat 2 (4):81-84.

61. Srimongkol PS, Thongchul N, Phunpruch S, Karnchanatat A (2019) Ability of marine cyanobacterium Synechococcus VDW to remove ammonium from brackish aquaculture wastewater. Agric Water Manag 212(1):155-161. DOI: https://doi.org/10.1016/j.agwat.2018.09.006.

62. Talero E, Maurino SG, Roman JA, Luna AR, Alcaide A, Motilva V (2015) Bioactive Compounds Isolated from Microalgae in Chronic Inflammation and Cancer. Mar drugs 13:6152-6209. DOI: 10.3390/md13106152.

63. Tan BL, Norhaizan ME, Liew WPP, Rahman HS (2018) Antioxidant and Oxidative Stress: A Mutual Interplay in Age-Related Diseases. Front Pharmacol 9:1162. DOI: 3389/fphar.2018.01162.

64. Tan JS, Lee SY, Chew KW, Lam MK, Lim JW, Ho SH, Show PL (2020) A review on microalgae cultivation and harvesting, and their biomass extraction processing using ionic liquids. Bioengineered 11(1):116-129. https://doi.org/10.1080/21655979.2020.1711626

65. Tiwari A, Sharma A (2013a) Antifungal activity of anabaena variabilis against plant pathogens. Int J Pharm Bio Sci 4(2):1030 - 1036.

66. Tiwari A, Sharma D (2013b) Antibacterial Activity of Bloom forming Cyanobacteria against Clinically Isolated Human Pathogenic Microbes. J Algal Biomass UtIn 4 (1):83-89: 2229- 6905.

67. Tossavainen M, Lahti K, Edelmann M, Eskola R, Lampi AM, Piironen V, Korvonen P, Ojala A, Romantschuk M (2018) Integrated utilization of microalgae cultured in aquaculture wastewater: wastewater treatment and production of valuable fatty acids and tocopherols. J Appl Phycol 31:1753-1763. https://doi.org/10.1007/s10811-018-1689-6.

68. Use of algae as aquafeed to improve production (2015) https://cdn2.hubspot.net/hubfs/4822820/OriginClear\%20August\%202018/PDF/white-paper-algaeas-aquafeed.pdf

69. Wells ML, Potin P, Craigie JS, Raven JA, Merchant SS, Helliwell KE, Smith AG, Camire ME, Brawley SH (2017) Algae as nutritional and functional food sources: revisiting our understanding. J Appl Phycol 29(2):949-982. DOI: 1007/s10811-016-0974-5.

70. Xing RL, Ma WW, Shao YW, Cao XB, Su C, Song H, Su Q, Zhou G (2018) Growth and potential purification ability of Nitzschia benthic diatoms in sea cucumber aquaculture wastewater. Aquac Res 9:1-9. DOI: 10.1111/are.13722.

71. Yarnold J, Karan H, Oey M, Hankamer B (2019) Microalgal Aquafeeds As Part of a Circular Bioeconomy. Trends Plant Sci 24(10):959-970. DOI: https://doi.org/10.1016/j.tplants.2019.06.005. 
72. Yew GY, Lee SY, Show PL, Tao Y, Law CL, Nguyen TTC, Chang JS (2019) Recent advances in algae biodiesel production: From upstream cultivation to downstream processing. Bioresour Technol Rep 7:100227. DOI: https://doi.org/10.1016/j.biteb.2019.100227.

73. Zullaikah S, Utomo AT, Yasmin M, Ong LK, Ju YH (2019) Eco-fuel conversion technology of inedible lipid feedstocks to renewable fuel. In book: Advances in Eco-Fuels for a Sustainable Environment. 237-276. https://doi.org/10.1016/B978-0-08-102728-8.00009-7.

\section{Figures}

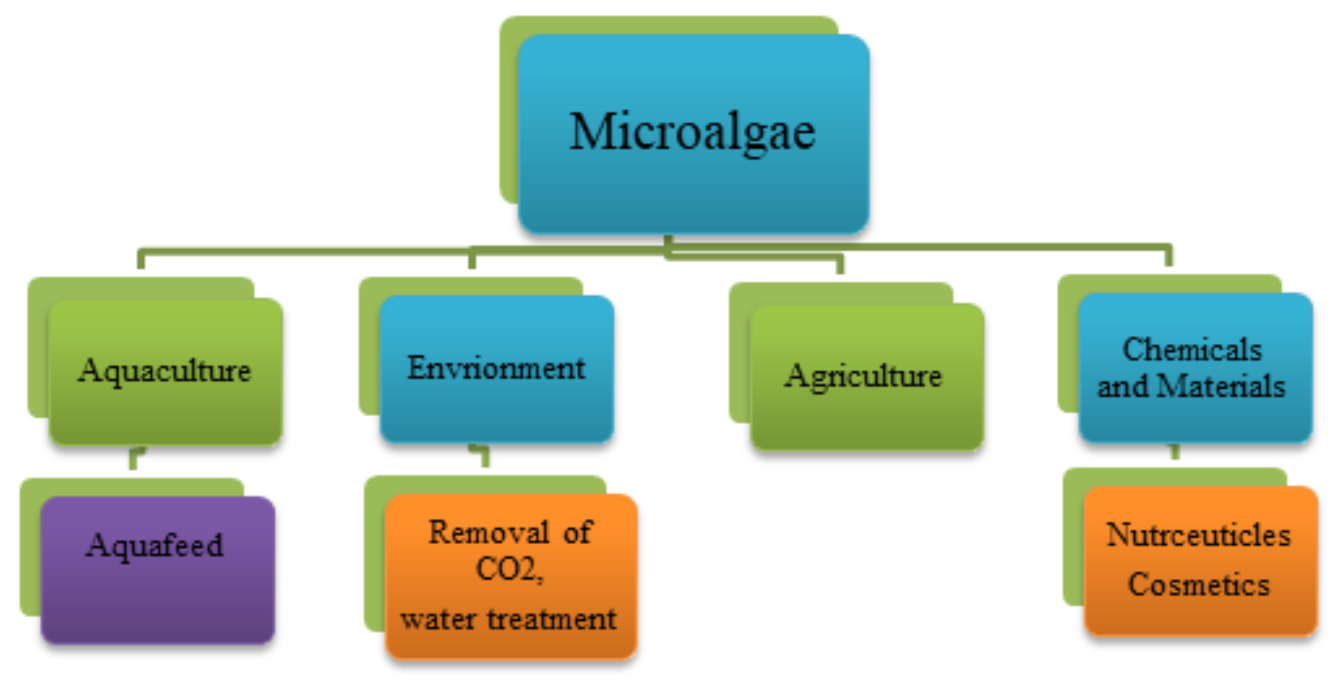

\section{Figure 1}

Applications of Microalgae

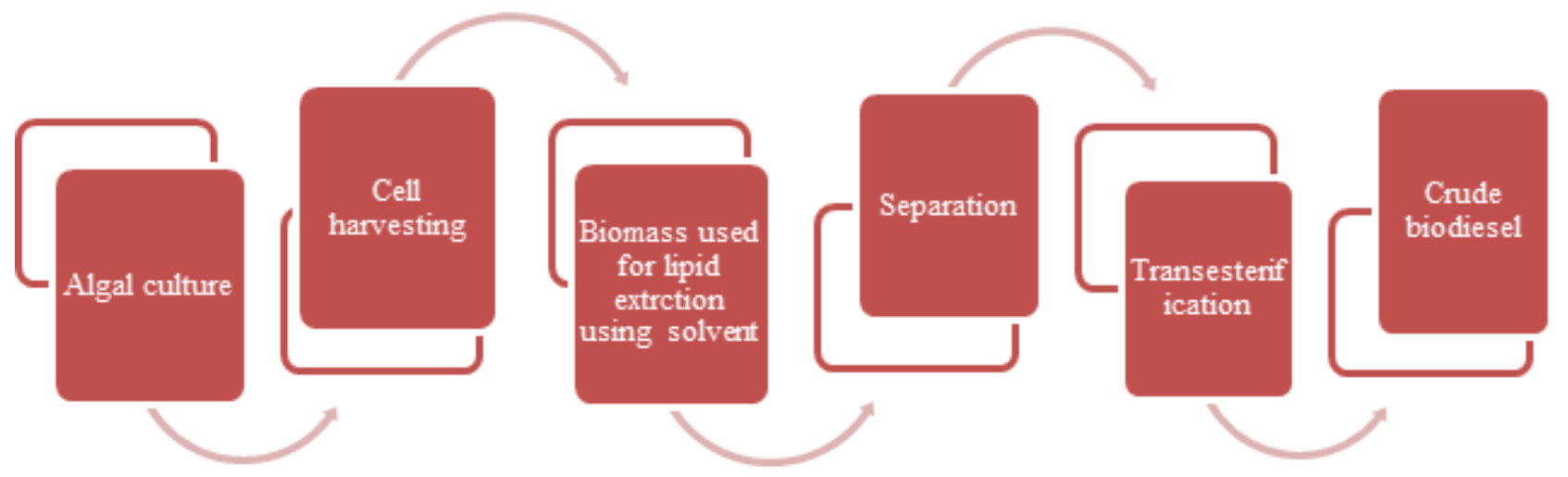

\section{Figure 2}




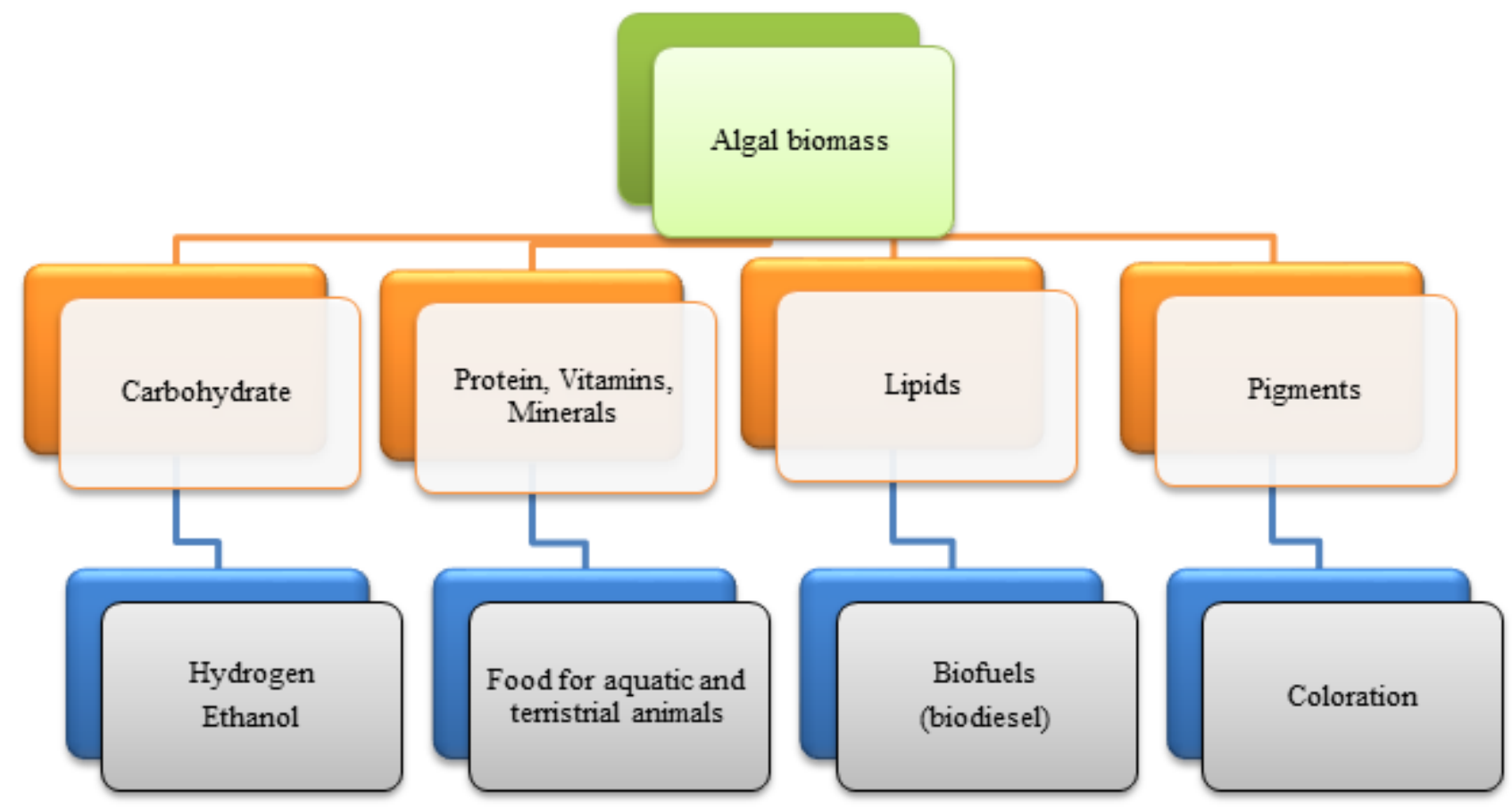

Figure 3

Applications of Algal Biomass

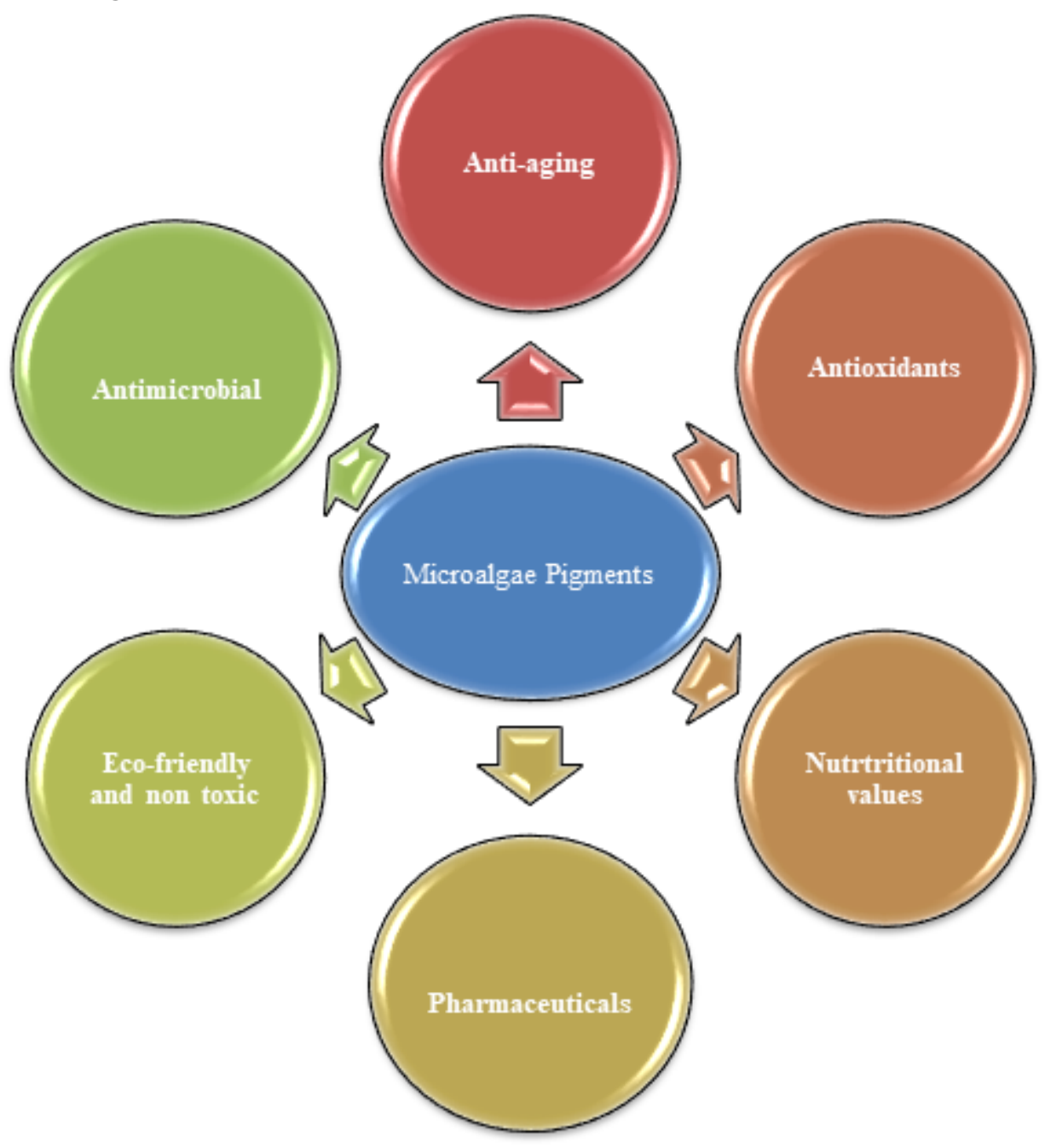

Page 22/24 
Figure 4

Applications of Microalgal Pigments

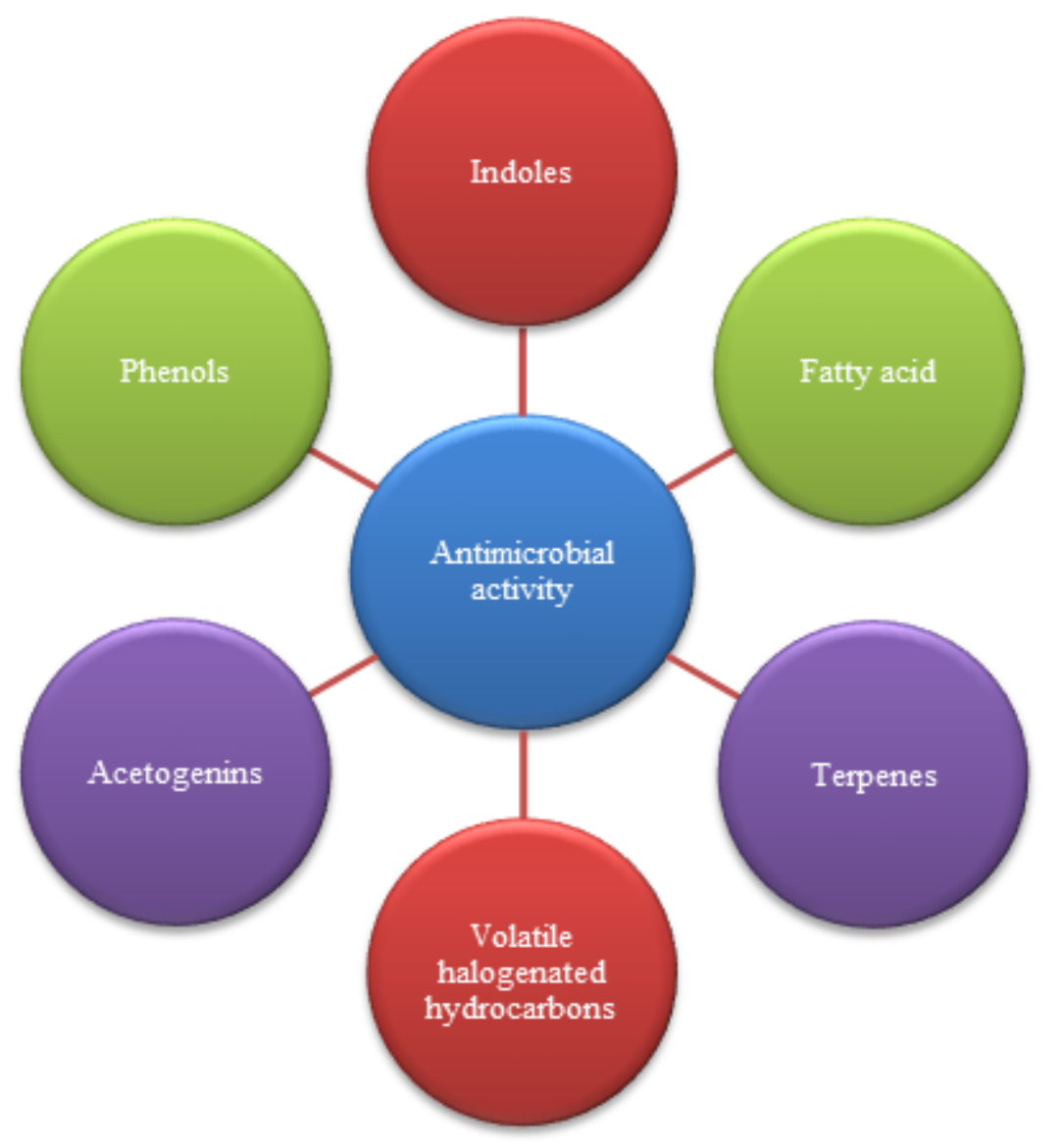

\section{Figure 5}

Factors behind the antimicrobial efficacy of Microalgae
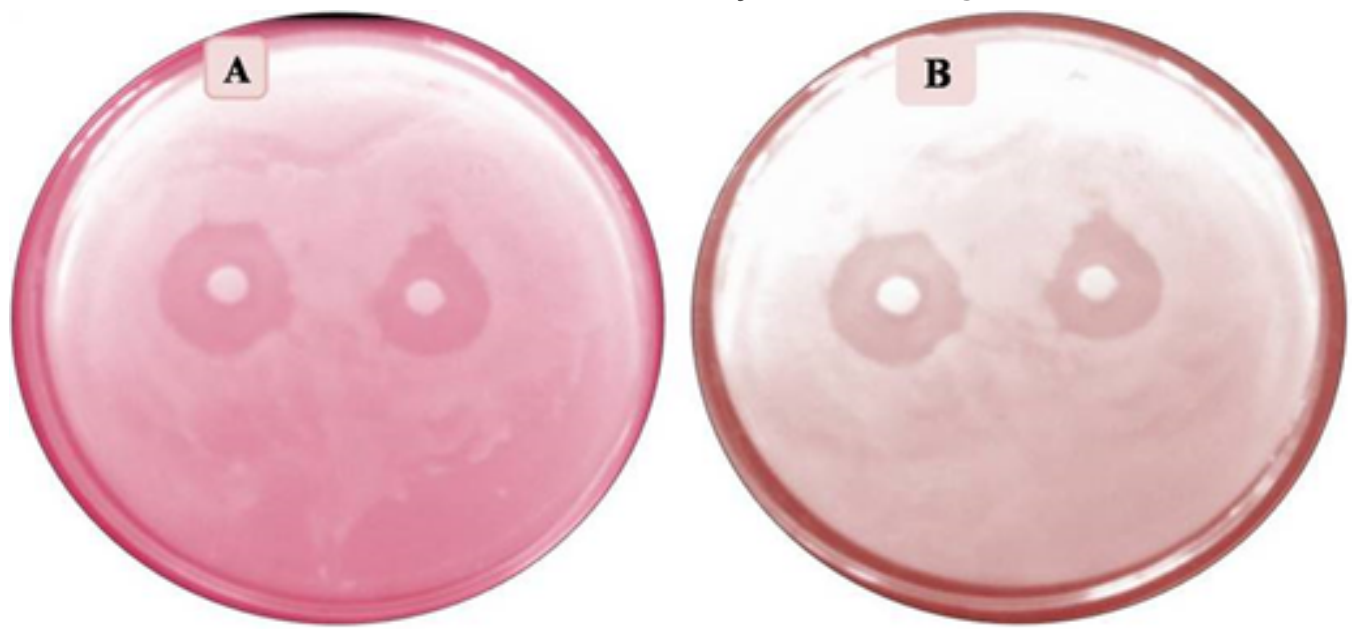

Figure 6

Inhibitory effect of Algal extracts against pathogenic organisms. 


\section{Supplementary Files}

This is a list of supplementary files associated with this preprint. Click to download.

- GA.jpg 